\title{
The Growth and Morphological Behavior of Salivary Epithelial Cells on Matrix Protein-Coated Biodegradable Substrata
}

\author{
D.J. AFRAMiAN, D.M.D., M.Sc., ${ }^{1}$ E. CUKIERMAN, Ph.D., ${ }^{2}$ J. NIKOLOVSKI, M.S., ${ }^{3}$ \\ D.J. MOONEY, Ph.D., ${ }^{4}$ K.M. YAMADA, M.D., Ph.D., ${ }^{2}$ and B.J. BAUM, D.M.D., Ph.D. ${ }^{1}$
}

\begin{abstract}
The purpose of this study was to examine the growth and morphology of a salivary epithelial cell line (HSG) in vitro on several biodegradable substrata as an important step toward developing an artificial salivary gland. The substrates examined were poly-(L)-lactic acid (PLLA), polyglycolic acid (PGA), and two co-polymers, $85 \%$ and $50 \%$ PLGA, respectively. The substrates were formed into 20- to $25-\mathrm{mm}$ disks, and the cells were seeded directly onto the polymers or onto polymers coated with specific extracellular matrix proteins. The two copolymer substrates became friable over time in aqueous media and proved not useful for these experiments. The purified matrix proteins examined included fibronectin (FN), laminin (LN), collagen I, collagen IV, and gelatin. In the absence of preadsorbed proteins, HSG cells did not attach to the polymer disks. The cells, in general, behaved similarly on both PLLA and PGA, although optimal results were obtained consistently in PLLA. On FN-coated PLLA disks, HSG cells were able to form a uniform monolayer, which was dependent on time and FN concentration. Coating of disks with $L N$, collagen $I$, and gelatin also promoted monolayer growth. This study defines the conditions necessary for establishing a monolayer organization of salivary epithelial cells with rapid proliferation on a biodegradable substrate useful for tissue engineering.
\end{abstract}

\section{INTRODUCTION}

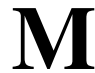
AMMALIAN SALIVARY GLANDS are compact parenchymal tissues consisting of both secretory and absorptive epithelial cells. ${ }^{1}$ Acinar cells comprise the major glandular cell type. They are salt secreting and are considered to be the exclusive site of fluid movement in these glands. ${ }^{1,2}$ Ductal cells are salt absorbing and are considered to be relatively water impermeable. ${ }^{1,2}$ Importantly, both epithelial cell types exist as a continuous, polarized monolayer along an extensively arborized luminal system, which opens directly into the mouth. ${ }^{1}$ The principal purpose of these glands is to secrete saliva, an exocrine secretion that

\footnotetext{
${ }^{1}$ Gene Therapy and Therapeutics Branch and, ${ }^{2}$ Craniofacial Developmental Biology and Regeneration Branch, National Institute of Dental and Craniofacial Research, National Institutes of Health, Bethesda, Maryland.

${ }^{3}$ Biomedical Engineering, ${ }^{4}$ Biologic and Materials Sciences and Chemical Engineering, University of Michigan, Ann Arbor, Michigan, Michigan.
} 
serves a primary protective role for the mouth. ${ }^{3}$ Saliva functions to mediate oral microbial colonization, mucosal repair, dental remineralization, food bolus formation and translocation, lubrication, and gustation.

Approximately 40,000 new cases of head and neck cancer occur each year in the United States, with an additional 500,000 new cases worldwide. ${ }^{4}$ In the industrial countries, the majority of these patients receive irradiation (IR) that includes the salivary glands in the radiation field. If the therapeutic IR treatment exceeds $\sim 50 \mathrm{~Gy}$, irreversible damage occurs to the salivary glands. ${ }^{5}$ This results primarily in the destruction of acinar cells, which are highly sensitive to IR. ${ }^{6}$ In many individuals, all salivary epithelial cells are replaced by nonsecretory tissue ${ }^{6}$ which leads to a persistent salivary hypofunction with marked reductions in salivary output. ${ }^{7}$ Patients consequently suffer from rampant dental caries, frequent mucosal infections, dysphagia, as well as considerable pain and discomfort. ${ }^{8}$ At present there is no effective conventional therapy for this condition.

We have initiated a program to develop an artificial salivary gland for patients with such IR damage, or with salivary parenchymal loss due to other causes, e.g., the autoimmune exocrinopathy Sjögren's syndrome. The device we envision would consist of a blind-end tube made out of a porous, slowly biodegradable substratum, coated with matrix components on the inner (luminal) surface of the tube to promote formation of a polarized epithelial cell monolayer. This device would be implanted in the buccal mucosal tissue with an "exit" to the oral cavity, mimicking the orifices of the natural salivary duct system. ${ }^{9,10}$ The purpose of the present study was to examine the growth and organizational behavior of a potential allogeneic graft cell on biodegradable polymers that were coated or not with different matrix protein preparations. We view this as an important initial step in developing an artificial salivary gland.

\section{MATERIALS AND METHODS}

\section{Polymer disk preparation}

Two-dimensional films of poly-(L)-lactic acid (PLLA) (Boehringer Ingelheim Inc., Winchester, VA), polyglycolic acid (PGA), and two copolymers, 50/50 PLGA and 85/15 PLGA (Alkermes, Cincinnati, OH) were produced by melt-processing polymer pellets between sheets of aluminum foil using a Carver press at $350^{\circ} \mathrm{F}, 450^{\circ} \mathrm{F}, 175^{\circ} \mathrm{F}$, and $200^{\circ} \mathrm{F}$ for PLLA, PGA, 50/50 PLGA, and 85/15 PLGA, respectively, to create disks with diameters of $20-25 \mathrm{~mm}$. The disks were sterilized using gamma-irradiation for $\sim 150 \mathrm{~min}$ with a dose of $2.01 \mathrm{Mrad}$.

\section{Matrix proteins}

Extracellular matrix proteins were obtained from the following sources: collagen I (Vitrogen; Collagen Biomaterials, Palo Alto, CA), collagen IV (Trevigen, Gaithersburg, MD), and laminin (LN; Gibco BRL, Gaithersburg, MD). Human fibronectin (FN) was prepared as described by Miekka et al. ${ }^{11}$ Gelatin was obtained from ICN Pharmaceuticals, Inc. (Costa Mesa, CA).

\section{Cell culture}

HSG cells were a generous gift from Prof. M. Sato (Tokushima University, Japan) ${ }^{12}$ and were maintained in vitro as previously described. ${ }^{13}$ For the experiments presented herein, HSG cells were removed from confluent plates using a solution of Versene 1:5000 in Hanks' balanced salt solution without calcium and magnesium (BioFluids, Rockville, MD). Cells were then resuspended in fresh media consisting of a 1:1 mixture of Eagle's minimal essential medium, Dulbecco's modification, and Ham's F-12 supplemented with $2 \mathrm{mM}$ glutamine (BioFluids, Rockville, MD), 10\% fetal calf serum (FCS; Hyclone, Logan, UT), and 100 units/mL penicillin, $100 \mu \mathrm{g} / \mathrm{mL}$ streptomycin, and $2.5 \mu \mathrm{g} / \mathrm{mL}$ fungizone (BioFluids, Rockville, MD).

\section{Matrix protein adsorption to polymer disks}

The sterilized disks were either immersed in phosphate-buffered saline (PBS; Gibco BRL, Grand Island, NY) or coated with one of the following proteins in PBS: collagen I, FN, gelatin, collagen IV, or LN. Disks were coated by incubation in solutions of the different matrix proteins for $18 \mathrm{~h}$. In several experiments, 
disks were also coated with FCS. Thereafter, the individual disks were gently placed in each well of a sixwell tissue culture plate (Becton Dickinson, Franklin Lakes, NJ) and incubated at $37^{\circ} \mathrm{C}$ for $\sim 18 \mathrm{~h}$. If appropriate (see figure legends), the coated disks were next blocked for $1 \mathrm{~h}$ with bovine serum albumin (BSA; Calbiochem-Novabiochem Corp., La Jolla, CA) at $37^{\circ} \mathrm{C}$ and then gently washed twice with PBS. BSA was used to occupy remaining nonspecific adsorption sites for matrix proteins on the disks, thereby preventing nonspecific cell adherence. ${ }^{14}$ Cell suspensions were added to the wells in complete culture media (i.e., with FCS) and incubated at $37^{\circ} \mathrm{C}$.

\section{Measurement of HSG cell number and organization}

At the indicated times, the disks were removed from wells, washed twice in PBS, and then stained with $0.2 \%$ crystal violet in $20 \%$ ethanol for 20 min. Next, the disks were rinsed twice with PBS and examined under a light microscope using $100 \times$ magnification. Three randomly selected photomicrographs were obtained from each specimen using 200 ASA color slide film (Elite chrome, Kodak, Rochester, NY). Thereafter, the slides were scanned to convert them to digital images. Using Adobe Photoshop ${ }^{\circledR}$, three $200-\mu \mathrm{m}^{2}$ regions were randomly chosen from each field; the cell number was determined manually and cell organization was studied. Cell number was counted directly from the scanned image on a printed computer display. Organization was assessed for the presence of a monolayer, size of cells, existence of clumps, presence of spaces between cells, as well as the relative homogeneity and overall morphology of the cells in culture.

\section{RESULTS}

\section{HSG cell growth on different polymers}

In the absence of any protein coating, HSG cells were unable to attach to any polymer surface examined by us (not shown). However as shown in Fig. 1, after coating disks with 10\% FCS, HSG cells could attach

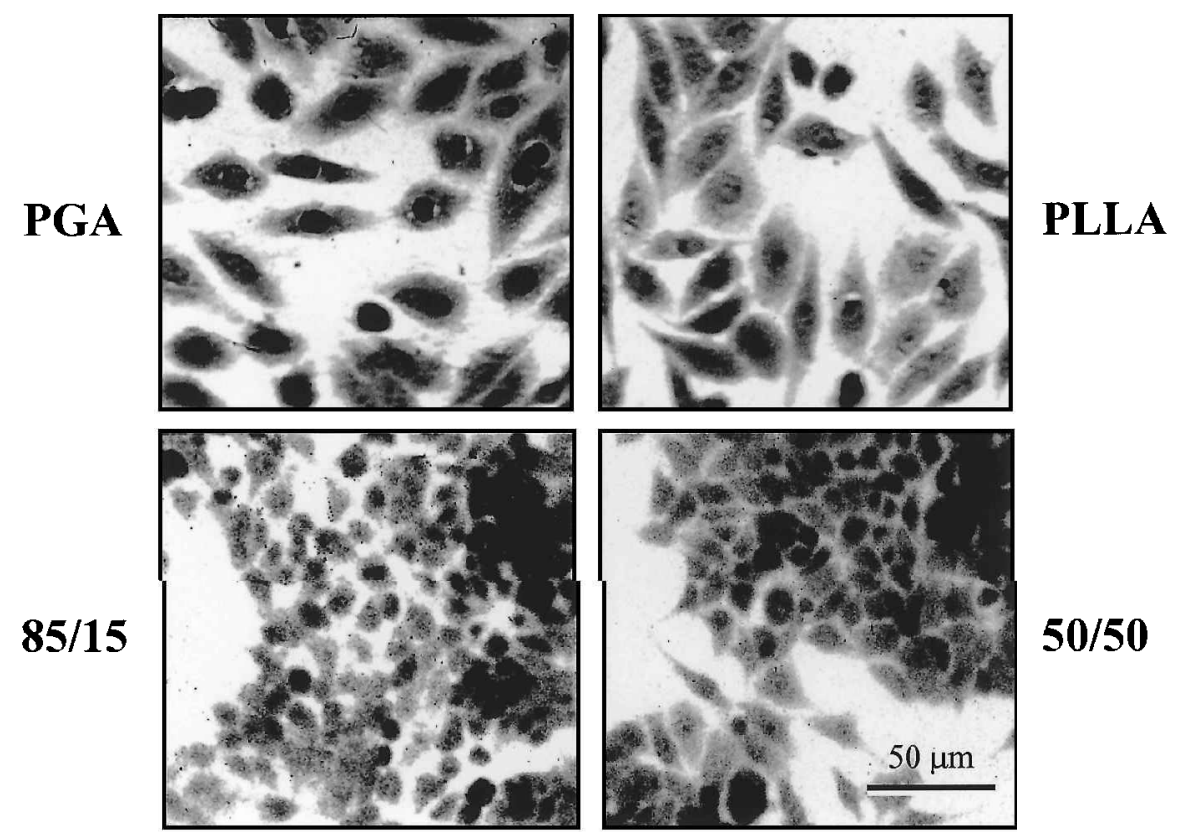

FIG. 1. HSG cell grow th on biodegradable polymers. The PGA, PLLA, 50/50, or 85/15 copolymer disks were incubated overnight in tissue culture medium containing $10 \%$ FCS. Then, HSG cells were seeded on disks for an additional overnight period, and the cells were stained with crystal violet. Randomly chosen areas of the disks are shown. 
and grow on all of the biodegradable polymers, i.e., PLLA, PGA, and the 50/50 and 85/15 copolymers. Cells grown on PLLA and PGA were similar in appearance and morphology, but quite different from cells grown on both copolymers. Growth on the latter appeared to result in an uneven cell distribution. It was difficult to use both copolymers because they were brittle in the aqueous medium and fragmented easily over time in culture. Hence, further studies utilized only the PLLA and PGA disks.

\section{HSG cell growth in the presence of different matrix proteins}

HSG cells $\left(5 \times 10^{5}\right.$ cells $\left./ \mathrm{mL}\right)$ were seeded on disks coated with different matrix proteins, incubated for $24 \mathrm{~h}$, and then stained with crystal violet. Results of initial experiments comparing PLLA and PGA disks were quite similar regarding the effect of each matrix protein coating on HSG cell growth, although backgrounds tended to be lower, and signals higher, with PLLA. For that reason we chose to examine in detail only cell-to-matrix protein interactions on PLLA disks. In the absence of any protein coating, or if the PLLA disks were first blocked with BSA overnight and then coated with $10 \%$ FCS, little to no HSG cell attachment occurred (Fig. 2). Conversely, all of the other protein solutions used were able to mediate cell attachment to polymer disks. As a positive control, 10\% FCS was used without pretreatment with BSA. In the presence of FCS we observed $\sim 850$ cells $/ \mathrm{mm}^{2}$. When disks were coated with either FN, LN, or gelatin, HSG cell adherence was somewhat higher $\left(\sim 900-1000\right.$ cells $\left./ \mathrm{mm}^{2}\right)$. When the disks were coated with either collagen I or IV, levels of cell adhesion were similar to those seen with 10\% FCS (Fig. 2). Results with FN showed the least variability in cell number, and the most consistent monolayer morphology. For these reasons, and particularly because FN is a human protein that can be readily obtained, we chose to examine in more detail the FN-mediated adherence of HSG cells to the PLLA disks.

\section{Kinetic evaluation of HSG cell growth and morphology on FN-coated PLLA disks}

At different time points after seeding of HSG cells on the PLLA disks, we examined their growth and appearance (Fig. 3). For these experiments, the PLLA disks were coated with FN $(20 \mu \mathrm{g} / \mathrm{mL})$, and the cells were incubated for up to 5 days. As shown in Fig. 3, HSG cell growth was time dependent. Cell number increased slowly over the first 2 days and then in rapid, exponential fashion until day 4 . Thereafter, cell

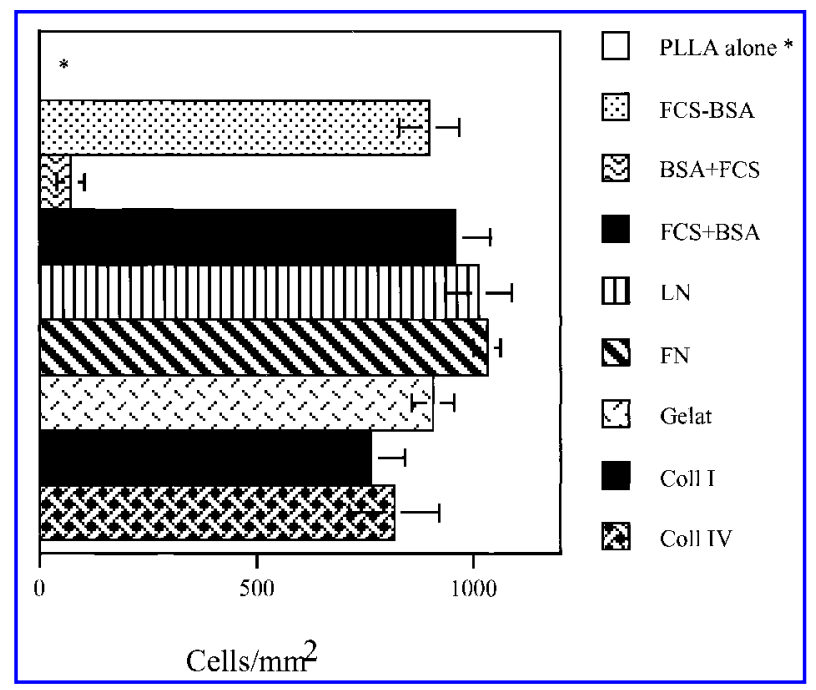

FIG. 2. HSG cell growth on PLLA disks coated with different adhesive proteins. HSG cells $\left(5 \times 10^{5}\right.$ cells $/ \mathrm{mL} ; 2$ $\mathrm{mL}$ ) were seeded on PLLA disks and incubated for $24 \mathrm{~h}$ at $37^{\circ} \mathrm{C}$ and $5 \% \mathrm{CO}_{2}$. Thereafter cells were stained as in Fig. 1. Data are the mean \pm SEM of nine separate determinations. Abbreviations used are fetal calf serum (FCS), bovine serum albumin (BSA), laminin (LN), fibronectin (FN), gelatin (Gelat), collagen I (Coll I), collagen IV (Coll IV). All individual proteins were used at $20 \mu \mathrm{g} / \mathrm{mL}$ and FCS was at $10 \%$. 


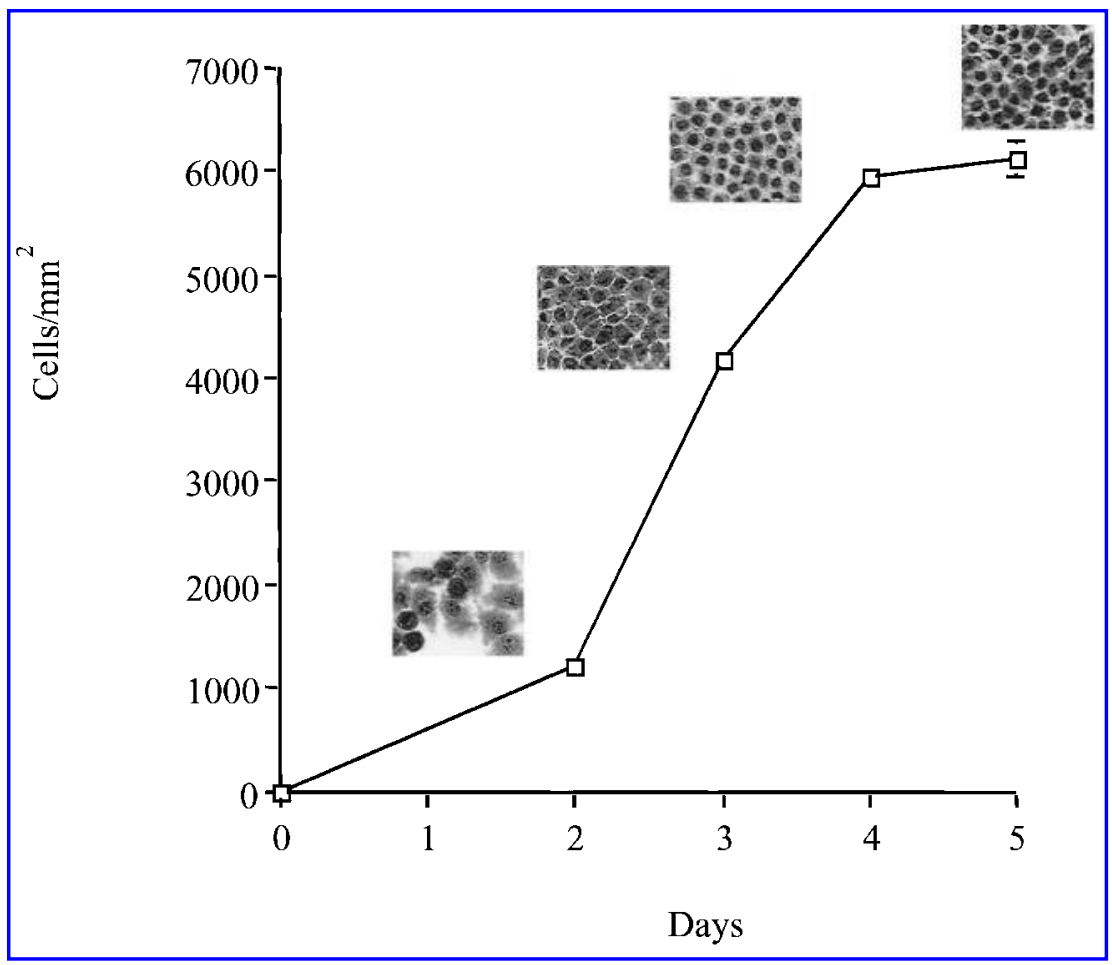

FIG. 3. Time course of HSG cell growth on FN-coated PLLA. HSG cells $\left(5 \times 10^{5}\right.$ cells $\left./ \mathrm{mL} ; 2 \mathrm{~mL}\right)$ were seeded on PLLA disks after coating overnight with fibronectin $(20 \mu \mathrm{g} / \mathrm{mL})$, and incubated for $0,2,3,4$, and 5 days. Data are the mean \pm SEM of nine separate determinations. Where error bars are not visible, they were less than the symbol size used.

number plateaued as growth ceased. The FN-coated disks assumed a densely packed, epithelioid monolayer morphology over this time course.

\section{Effect of FN concentration on HSG cell growth}

We lastly examined HSG cell growth over $72 \mathrm{~h}$ on PLLA disks coated with different concentrations of FN ranging from 0.02 to $20.0 \mu \mathrm{g} / \mathrm{mL}$ (Fig. 4). The effect of FN coating was concentration-dependent. Halfmaximal growth occurred with $\sim 0.2 \mu \mathrm{g} / \mathrm{mL} \mathrm{FN}$ coated onto the disks, with maximal growth seen at both 2.0 and $20 \mu \mathrm{g} / \mathrm{mL}$ FN.

\section{DISCUSSION}

The purpose of this study was to examine the ability of different biodegradable polymers to support the growth of a human salivary epithelial cell line in the presence of purified matrix proteins. As such, the study represents an important step toward the development of an artificial salivary gland for individuals whose secretory tissue has been lost. Patients who have lost all functional salivary epithelium, e.g., those with Sjögren's syndrome or post-irradiation for head and neck cancer, experience severe salivary hypofunction resulting in a markedly diminished quality of life. There is no effective conventional therapy for these patients. In the absence of glandular epithelium, pharmacological therapies using secretogogues, ${ }^{15}$ or gene therapy, ${ }^{16}$ are not possible. Although salivary gland transplantation is an option, ${ }^{17}$ it is not likely to be practical because of an insufficient donor supply, the need for continuous immunosuppression, and the surgical difficulty.

Using now well-accepted principles of tissue engineering, ${ }^{18,19}$ we have begun to explore the fabrication of an orally implantable fluid-secreting device. Homopolymers of lactic or glycolic acid, or certain of their 


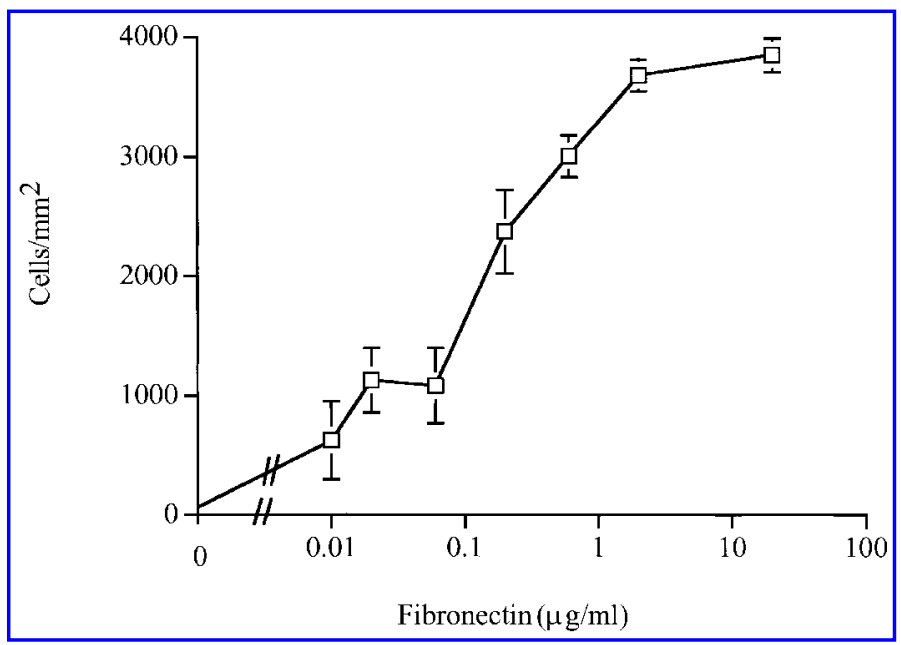

FIG. 4. Effect of fibronectin concentration on HSG cell growth. HSG cells $\left(5 \times 10^{5}\right.$ cells $\left./ \mathrm{mL} ; 2 \mathrm{~mL}\right)$ were seeded on PLLA disks precoated with different fibronectin concentrations $(0,0.01,0.02,0.2,0.6,2$, and $20 \mu \mathrm{g} / \mathrm{mL})$, cultured for $72 \mathrm{~h}$, and thereafter stained with crystal violet as in Fig. 1. Cell number was determined as described in Materials and Methods. Data are the mean \pm SEM of nine separate determinations.

copolymers, are biocompatible and have been useful as scaffolds in efforts to build other artificial tissues. ${ }^{20-22}$ As a model test cell, we employed the HSG cell line. ${ }^{12}$ HSG cells are well-studied, ${ }^{23-26}$ and exhibit functionally coupled neurotransmitter receptors, ${ }^{27,28}$ intact $\mathrm{Ca}^{2+}$ signaling systems, ${ }^{29,30}$ and various ion channels and transporters ${ }^{31}$; all of these systems are necessary to generate the osmotic gradients required for saliva formation. ${ }^{1,2}$ Additionally, HSG cells respond to extracellular matrix signals that can direct morphological and genetic differentiation. ${ }^{32-34}$ Furthermore, HSG cells are useful for gene transfer ${ }^{35}$ and are known to use established salivary cell-specific promoter elements. ${ }^{36}$

Because native salivary epithelia exist essentially as a monolayer lining a lumen, ${ }^{1}$ the ideal substratum should induce the formation of a monolayer of polarized cells. Therefore, we focused on determining conditions that would stimulate HSG cell growth on the various polymers as a continuous monolayer. Both copolymers used by us (50/50 and 85/15 PLGA) proved too brittle for the manipulations required in our experiments. Both homopolymers, PLLA and PGA, supported HSG cell growth and organizational behavior when coated with certain individual matrix proteins. However, results with PLLA were considerably more reproducible and less variable. In general, cell growth on substrates coated with either pure FN or LN provided optimal results, i.e., highest cell number and continuous monolayer, while growth on either native (I, IV) or denatured (I, gelatin) collagens was not as effective in this regard. FN is relatively easy to purify in substantial amounts from human plasma, compared to $\mathrm{LN}$ which must be extracted from basement membranes. Thus, FN appears to be preferable as a coating for support of salivary epithelial cell growth on these biodegradable substrates.

If an allogeneic cell line is desired, HSG cells are a valuable candidate. However, as a cell line, they possess unlimited growth potential. For this reason our future plans include incorporating the use of a suicide gene as a safety factor with these cells to limit possible host compromise. Also, they have not yet been shown to express facilitated water permeability pathways ${ }^{37}$ such as those needed for stimulus-coupled salivary flow. Furthermore, although HSG cells yield a classic epithelioid "cobblestone" appearance when grown on FN-coated PLLA, it needs to be established if these cells are both functionally polarized and possess functional junctional complexes such as required for unidirectional fluid secretion. ${ }^{38} \mathrm{HSG}$ cell use may require substantial genetic engineering to obtain the needed cellular characteristics. Conversely, the use of autologous, amplified epithelial cells for a graft device would be ideal, but the growth of acinar (fluid-secreting) mammalian epithelial cells in vitro has thus far been elusive. Although the current studies demonstrate significant progress toward our desired goal, the development of an artificial salivary gland will require considerable additional work. 


\section{SALIVARY CELL GROWTH ON COATED POLYMERS}

\section{REFERENCES}

1. Cook, D.I., Van Lennep, E.W., Roberts, M.L., and Young, J.A. Secretion by the major salivary glands. In: Johnson, L.R., ed. Physiology of the Gastrointestinal Tract. New York: Raven, 1994, p. 1061.

2. Baum, B.J. Principles of saliva secretion. Ann N.Y. Acad Sci. 694, 17, 1993.

3. Mandel, I.D. The role of saliva in maintaining oral homeostasis. J. Am. Dent. Assoc. 119, $298,1989$.

4. Vokes, E.E., Weichselbaum, R.R., Lippman, S.M., and Hong, W.K. Head and neck cancer. N. Engl. J. Med. 328, 184, 1993.

5. Franzen, L., Funegard, U., Ericson, T., and Henriksson, R. Parotid gland function during and following radiotherapy of malignancies in the head and neck. A consecutive study of salivary flow and patient discomfort. Eur. J. Cancer 28, 457, 1992.

6. Kashima, H.K., Kirkham, J.R., and Andrews, J.R. Postirradiation sialadenitis. A study of the clinical features, histopathologic changes and serum enzyme variations following irradiation of human salivary glands. Am. J. Roentgenol. Radium Ther. Nucl. Med. 94, 77, 1965.

7. Valdez, I.H., Atkinson, J.C., Ship, J.A., and Fox, P.C. Major salivary gland function in patients with radiation-induced xerostom ia: flow rates and sialochem istry. Int. J. Radiat. Oncol. Biol. Phys. 25, 41, 1993.

8. Fox, P.C. Acquired salivary dysfunction. Drugs and radiation. Ann. N.Y. Acad. Sci. 842, $132,1998$.

9. Baum, B.J., Wang, S., Cukierman, E., Delporte, C., Kagami, H., Marmary, Y., Fox, P.C., Mooney, D.J., and Yamada, K.M. Re-engineering the functions of a terminally-diffe rentiated epithelial cell in vivo. Ann. N.Y. Acad. Sci. 875, 294, 1999.

10. Wang, S., Cukierman, E., Swaim, W.D., Yamada, K.M., and Baum, B.J. Extracellular matrix protein-induced changes in human salivary epithelial cell organization and proliferation on a model biological substratum. Biomaterials 20, 1043, 1999.

11. Miekka, S.I., Ingham, K.C., and Menache, D. Rapid methods for isolation of human plasma fibronectin. Thromb. Res. 27, 1, 1982.

12. Shirasuna, K., Sato, M., and Miyazaki, T. A neoplastic epithelial duct cell line established from an irradiated human salivary gland. Cancer 48, 745, 1981.

13. He, X.J., Wu, X.Z., and Baum, B.J. The effect of N-(6-aminohexyl)-5-chloro-1-naphthalenesulf onamide (W-7) on muscarinic receptor-induced $\mathrm{Ca}^{2+}$ mobilization in a human salivary epithelial cell line. Pflugers Arch. 416, 36, 1990.

14. Wedege, E., and Sveeneby, G. Effects of the blocking agents bovine serum albumin and Tween 20 in different buffers on immunoblotting of brain proteins and marker proteins. J. Immunol. Methods 88, $233,1986$.

15. Fox, P.C., Atkinson, J.C., Macynski, A.A., Wolff, A., Kung, D.S., Valdez, I.H., Jackson, W., Delapenha, R.A., Shiroky, J., and Baum, B.J. Pilocarpine treatment of salivary gland hypofunction and dry mouth (xerostomia). Arch. Intern. Med. 151, 1149, 1991.

16. Delporte, C., O’Connell, B.C., He, X., Lancaster, H.E., O’Connell, A.C., Agre, P., and Baum, B.J. Increased fluid secretion after adenoviral-mediated transfer of the aquaporin-1 cDNA to irradiated rat salivary glands. Proc. Natl. Acad. Sci. USA 94, 3268, 1997.

17. Eid, A., Nitzan, D.W., Shiloni, E., Neuman, A., and Marmary, Y. Salivary gland transplantation: a canine model. Transplantation 64, 679, 1997.

18. Mooney, D.J., and Rowley, J.A. Tissue engineering: integrating cells and materials to create functional tissue replacements. In: Park, K., ed. Controlled Drug Delivery, Washington, DC: ABC Books, 1997, p. 333.

19. Langer, R., and Vacanti, J.P. Artificial organs. Sci. Am. 273, 130, 1995.

20. Kim, B.S., Putnam, A.J., Kulik, T.J., and Mooney, D.J. Optimizing seeding and culture methods to engineer smooth muscle tissue on biodegradable polymer matrices. Biotechnol. Bioeng. 57, 46, 1998.

21. Wake, M.C., Patrick, C.W., and Mikos, A.G., Jr. Pore morphology effects on the fibrovascular tissue growth in porous polymer substrates. Cell Transplant. 3, 339, 1994.

22. Kaihara, S., Kim, S.S., Benvenuto, M., Choi, R., Kim, B.S., Mooney, D., Tanaka, K., and Vacanti, J.P. Successful anastomosis between tissue-engineered intestine and native small bowel. Transplantation 67, $241,1999$.

23. Hoffman, M.P., Kibbey, M.C., Letterio, J.J., and Kleinman, H.K. Role of laminin-1 and TGF-beta 3 in acinar differentiation of a human submandibular gland cell line (HSG). J. Cell Sci. 109, 2013, 1996.

24. Wu, A.J., Lafrenie, R.M., Park, C., Apinhasm it, W., Chen, Z.J., Birkedal-Hanse n, H., Yamada, K.M., Stetler-Stevenson, W.G., and Baum, B.J. Modulation of MMP-2 (gelatinase A) and MMP-9 (gelatinase B) by interferon-gamm a in a human salivary gland cell line. J. Cell. Physiol. 171, 117, 1997.

25. O’Connell, A.C., Lillibridge, C.D., Zheng, C., Baum, B.J., O’Connell, B.C., and Ambudkar, I.S. Gamma-irradiation-induced cell cycle arrest and cell death in a human submandibular gland cell line: effect of E2F1 expression. J. Cell. Physiol. 177, 264, 1998. 
26. Liu, X., Rojas, E., and Ambudkar, I.S. Regulation of $\mathrm{K}_{\mathrm{Ca}}$ current by store-operated $\mathrm{Ca}^{2+}$ influx depends on internal $\mathrm{Ca}^{2+}$ release in HSG cells. Am. J. Physiol. 275, C571, 1998.

27. Ship, J.A., Patton, L.L., and Wellner, R.B. Muscarinic regulation of potassium transport in a human submandibular epithelial cell line. Am. J. Physiol. 259, C340, 1990.

28. Liu, X., O'Connell, A., and Ambudkar, I.S. $\mathrm{Ca}^{2+}$-dependent inactivation of a store-operated $\mathrm{Ca}^{2+} \mathrm{current}$ in human submandibular gland cells. Role of a staurosporine-sen sitive protein kinase and the intracellular pump. J. Biol. Chem. 273, 33295, 1998.

29. Kaplan, M.D., Taylor, S.E., and Ambudkar, I.S. G-protein- and capacitatively regulated $\mathrm{Ca}^{2+}$ entry pathways are activated by muscarinic receptor stimulation in a human submandibular ductal cell line. Pflugers Arch. 428, 439, 1994.

30. He, X.J., Wu, X.Z., Turner, R.J., and Baum, B.J. Evidence for two modes of $\mathrm{Ca}^{2+}$ entry following muscarinic stimulation of a human salivary epithelial cell line. J. Membr. Biol. 115, 159, 1990.

31. Izutsu, K.T., Fatherazi, S., Wellner, R.B., Herrington, J., Belton, C.M., and Oda, D. Characteristics and regulation of a muscarinically activated K current in HSG-PA cells. Am. J. Physiol. 266, C58, 1994.

32. Royce, L.S., Kibbey, M.C., Mertz, P., Kleinman, H.K., and Baum, B.J. Human neoplastic submandibular intercalated duct cells express an acinar phenotype when cultured on a basement membrane matrix. Differentiation 52, 247, 1993.

33. Hoffman, M.P., Nomizu, M., Roque, E., Lee, S., Jung, D.W., Yamada, Y., and Kleinman, H.K. Laminin-1 and laminin-2 G-domain synthetic peptides bind syndecan-1 and are involved in acinar formation of a human submandibular gland cell line. J. Biol. Chem. 273, 28633, 1998.

34. Lafrenie, R.M., and Yamada, K.M. Integrins and matrix molecules in salivary gland cell adhesion, signaling, and gene expression. Ann. N.Y. Acad. Sci. 842, 42, 1998.

35. Mastrangeli, A., O’Connell, B., Aladib, W., Fox, P.C., Baum, B.J., and Crystal, R.G. Direct in vivo adenovirusmediated gene transfer to salivary glands. Am. J. Physiol. 266, G1146, 1994.

36. Zheng, C., Hoffman, M.P., McMillan, T., Kleinman, H.K., and O'Connell, B.C. Growth factor regulation of the amylase promoter in differentiating salivary gland acinar cells. J. Cell. Physiol. 177, 628, 1998.

37. King, L.S., and Agre, P. Pathophysiolog y of the aquaporin water channels. Annu. Rev. Physiol. 58, $619,1996$.

38. Mitic, L.L., and Anderson, J.M. Molecular architecture of tight junctions. Annu. Rev. Physiol. 60, $121,1998$.

Address reprint requests to:

Dr. Bruce J. Baum

GTTB, NIDCR, NIH

Bldg. 10, Rm $1 N 113$

MSC-1190

Bethesda, MD 20892

E-mail: bruce_j_baum@nih.gov 


\section{This article has been cited by:}

1. E. L. SCHELLER, P. H. KREBSBACH, D. H. KOHN. 2009. Tissue engineering: state of the art in oral rehabilitation. Journal of Oral Rehabilitation 36:5, 368-389. [CrossRef]

2. G. G. Poljanskaya, T. S. Goryachaya, G. P. Pinaev. 2009. Effect of immobilized laminin on karyotypic variability in two karyotypically different variants of the indian muntjac skin fibroblast cell line. Cell and Tissue Biology 2:6, 625-635. [CrossRef]

3. Timothy Douglas, Håvard J. Haugen. 2008. Coating of polyurethane scaffolds with collagen: comparison of coating and cross-linking techniques. Journal of Materials Science: Materials in Medicine 19:7, 2713-2719. [CrossRef]

4. Doron J. Aframian , Aaron Palmon . 2008. Current Status of the Development of an Artificial Salivary GlandCurrent Status of the Development of an Artificial Salivary Gland. Tissue Engineering Part B: Reviews 14:2, 187-198. [Abstract] [PDF] [PDF Plus]

5. N. Rotter, C. Wirz, J. Oder, B. Wollenberg, R. Huss, S. Brandau, S. Lang, M. Bücheler. 2008. Zellbasierte Strategien für die Speicheldrüsenregeneration. HNO 56:3, 281-287. [CrossRef]

6. Shiho Minamiguchi, Masaaki Takechi, Tetsuya Yuasa, Yukihiro Momota, Seiko Tatehara, Hideyuki Takano, Youji Miyamoto, Kazuhito Satomura, Masaru Nagayama. 2008. Basic research on aw-AC/PLGA composite scaffolds for bone tissue engineering. Journal of Materials Science: Materials in Medicine 19:3, 1165-1172. [CrossRef]

7. Ran David, Ela Shai, Doron J. Aframian, Aaron Palmon . 2008. Isolation and Cultivation of Integrin $a 6 \beta 1-$ Expressing Salivary Gland Graft Cells: A Model for Use with an Artificial Salivary GlandIsolation and Cultivation of Integrin $a 6 \beta 1-$ Expressing Salivary Gland Graft Cells: A Model for Use with an Artificial Salivary Gland. Tissue Engineering Part A 14:2, 331-337. [Abstract] [PDF] [PDF Plus]

8. Min-Huey Chen, Yi-Jane Chen, Chih-Chen Liao, Yen-Hui Chan, Chia-Yung Lin, Rung-Shu Chen, Tai-Hong Young. 2008. Formation of salivary acinar cell spheroids in vitro above a polyvinyl alcohol-coated surface. Journal of Biomedical Materials Research Part A 9999A, NA-NA. [CrossRef]

9. Ran David, Ela Shai, Doron J. Aframian, Aaron Palmon . Isolation and Cultivation of Integrin $\alpha 6 \beta 1-$ Expressing Salivary Gland Graft Cells: A Model for Use with an Artificial Salivary GlandIsolation and Cultivation of Integrin $\alpha 6 \beta 1-$ Expressing Salivary Gland Graft Cells: A Model for Use with an Artificial Salivary Gland. Tissue Engineering, ahead of print. [Abstract] [PDF] [PDF Plus]

10. H Kagami, S Wang, B Hai. 2007. Restoring the function of salivary glands. Oral Diseases, ahead of print070508213341001-???. [CrossRef]

11. Doron J. Aframian, Doron Amit, Ran David, Ela Shai, Dan Deutsch, Alexander Honigman , Amos Panet, Aaron Palmon . 2007. Reengineering Salivary Gland Cells to Enhance Protein Secretion for Use in Developing Artificial Salivary Gland DeviceReengineering Salivary Gland Cells to Enhance Protein Secretion for Use in Developing Artificial Salivary Gland Device. Tissue Engineering 13:5, 995-1001. [Abstract] [PDF] [PDF Plus]

12. Cindy Wei , Melinda Larsen, Matthew P. Hoffman, Kenneth M. Yamada . 2007. Self-Organization and Branching Morphogenesis of Primary Salivary Epithelial CellsSelf-Organization and Branching Morphogenesis of Primary Salivary Epithelial Cells. Tissue Engineering 13:4, 721-735. [Abstract] [PDF] [PDF Plus] [Supplementary material]

13. Shivaram Selvam, Padmaja B. Thomas, Melvin D. Trousdale, Douglas Stevenson, Joel E. Schechter, Austin K. Mircheff, Jean T. Jacob, Ronald E. Smith, Samuel C. Yiu. 2007. Tissue-engineered tear 
secretory system: Functional lacrimal gland acinar cells cultured on matrix protein-coated substrata. Journal of Biomedical Materials Research Part B: Applied Biomaterials 80B:1, 192-200. [CrossRef]

14. Simon D. Tran, Takayuki Sugito, Giovanni Dipasquale, Ana P. Cotrim, Bidhan C. Bandyopadhyay, Kathryn Riddle, David Mooney, Marc R. Kok, John A. Chiorini, Bruce J. Baum. 2006. Re-engineering Primary Epithelial Cells from Rhesus Monkey Parotid Glands for Use in Developing an Artificial Salivary Gland. Tissue Engineering, ahead of print060928130622002. [CrossRef]

15. Simon D. Tran, Takayuki Sugito, Giovanni Dipasquale, Ana P. Cotrim, Bidhan C. Bandyopadhyay , Kathryn Riddle , David Mooney, Marc R. Kok, John A. Chiorini , Bruce J. Baum . 2006. Re-engineering Primary Epithelial Cells from Rhesus Monkey Parotid Glands for Use in Developing an Artificial Salivary GlandRe-engineering Primary Epithelial Cells from Rhesus Monkey Parotid Glands for Use in Developing an Artificial Salivary Gland. Tissue Engineering 12:10, 2939-2948. [Abstract] [PDF] [PDF Plus]

16. Chi Hun Kim, Myung Seob Khil, Hak Yong Kim, Hyun Uk Lee, Kwang Yeop Jahng. 2006. An improved hydrophilicity via electrospinning for enhanced cell attachment and proliferation. Journal of Biomedical Materials Research Part B: Applied Biomaterials 78B:2, 283-290. [CrossRef]

17. Bruce J. Baum, Simon D. Tran. 2006. Synergy between genetic and tissue engineering: creating an artificial salivary gland. Periodontology 2000 41:1, 218-223. [CrossRef]

18. Min-Huey Chen, Rung-Shu Chen, Yuan-Hua Hsu, Yi-Jane Chen, Tai-Horng Young . 2005. Proliferation and Phenotypic Preservation of Rat Parotid Acinar CellsProliferation and Phenotypic Preservation of Rat Parotid Acinar Cells. Tissue Engineering 11:3-4, 526-534. [Abstract] [PDF] [PDF Plus]

19. Masahiro Kino-Oka, Shino Yashiki, Yuka Ota, Yuko Mushiaki , Katsura Sugawara, Takeyuki Yamamoto, Toshiaki Takezawa, Masahito Taya . 2005. Subculture of Chondrocytes on a Collagen Type I-Coated Substrate with Suppressed Cellular DedifferentiationSubculture of Chondrocytes on a Collagen Type I-Coated Substrate with Suppressed Cellular Dedifferentiation. Tissue Engineering 11:3-4, 597-608. [Abstract] [PDF] [PDF Plus]

20. S.D. Tran , J. Wang, B.C. Bandyopadhyay , R.S. Redman , A. Dutra , E. Pak , W.D. Swaim , J.A. Gerstenhaber, J.M. Bryant, C. Zheng, C.M. Goldsmith, M.R. Kok, R.B. Wellner, B.J. Baum . 2005. Primary Culture of Polarized Human Salivary Epithelial Cells for Use in Developing an Artificial Salivary GlandPrimary Culture of Polarized Human Salivary Epithelial Cells for Use in Developing an Artificial Salivary Gland. Tissue Engineering 11:1-2, 172-181. [Abstract] [PDF] [PDF Plus]

21. Elizabeth M. Cronin, Frederick A. Thurmond, Rhonda Bassel-Duby, R. Sanders Williams, Woodring E. Wright, Kevin D. Nelson, Harold R. Garner. 2004. Protein-coated poly(L-lactic acid) fibers provide a substrate for differentiation of human skeletal muscle cells. Journal of Biomedical Materials Research 69A:3, 373-381. [CrossRef]

22. D.J. Aframian , R. David , H. Ben-Bassat , E. Shai , D. Deutsch , B.J. Baum , A. Palmon . 2004. Characterization of Murine Autologous Salivary Gland Graft Cells: A Model for Use with an Artificial Salivary GlandCharacterization of Murine Autologous Salivary Gland Graft Cells: A Model for Use with an Artificial Salivary Gland. Tissue Engineering 10:5-6, 914-920. [Abstract] [PDF] [PDF Plus]

23. Arnaldo R. Santos, Betina M.P. Ferreira, Eliana A.R. Duek, Heidi Dolder, Ronaldo S. Wada, Maria Lucia F. Wada. 2004. Differentiation Pattern of Vero Cells Cultured on Poly(L-Lactic Acid)/Poly(Hydroxybutyrate-co-Hydroxyvalerate) Blends. Artificial Organs 28:4, 381-389. [CrossRef] 
24. S.S. Liao , F.Z. Cui . 2004. In Vitro and in Vivo Degradation of Mineralized Collagen-Based Composite Scaffold: Nanohydroxyapatite/Collagen/Poly(L-lactide)In Vitro and in Vivo Degradation of Mineralized Collagen-Based Composite Scaffold: Nanohydroxyapatite/Collagen/Poly(L-lactide). Tissue Engineering 10:1-2, 73-80. [Abstract] [PDF] [PDF Plus]

25. Chang-Hoon Kim, Jung Ho Bae, Seoyeon Son, Jung-Hyun Kim, Jeung-Gweon Lee, Joo-Heon Yoon. 2004. Use of PLGA scaffold for mucociliary epithelium transfer in airway reconstruction: a preliminary study. Acta Oto-Laryngologica 1:1, 0. [CrossRef]

26. M. Bücheler , A. Haisch . 2003. Tissue Engineering in Otorhinolaryngology Tissue Engineering in Otorhinolaryngology. DNA and Cell Biology 22:9, 549-564. [Abstract] [PDF] [PDF Plus]

27. Giuseppe Intini , Sebastiano Andreana, Joseph E. Margarone III , Peter J. Bush , Rosemary Dziak . 2002. Engineering a Bioactive Matrix by Modifications of Calcium SulfateEngineering a Bioactive Matrix by Modifications of Calcium Sulfate. Tissue Engineering 8:6, 997-1008. [Abstract] [PDF] [PDF Plus]

28. D.J. Aframian , S.D. Tran , E. Cukierman , K.M. Yamada , B.J. Baum . 2002. Absence of Tight Junction Formation in an Allogeneic Graft Cell Line Used for Developing an Engineered Artificial Salivary GlandAbsence of Tight Junction Formation in an Allogeneic Graft Cell Line Used for Developing an Engineered Artificial Salivary Gland. Tissue Engineering 8:5, 871-878. [Abstract] [PDF] [PDF Plus]

29. D.J. Aframian , R.S. Redman, S. Yamano, J. Nikolovski, E. Cukierman , K.M. Yamada , M.F. Kriete, W.D. Swaim, D.J. Mooney, B.J. Baum . 2002. Tissue Compatibility of Two Biodegradable Tubular Scaffolds Implanted Adjacent to Skin or Buccal Mucosa in MiceTissue Compatibility of Two Biodegradable Tubular Scaffolds Implanted Adjacent to Skin or Buccal Mucosa in Mice. Tissue Engineering 8:4, 649-659. [Abstract] [PDF] [PDF Plus]

30. Jonathan A. Ship, Stanley R. Pillemer, Bruce J. Baum. 2002. Xerostomia and the Geriatric Patient. Journal of the American Geriatrics Society 50:3, 535-543. [CrossRef]

31. JA Ship. 2002. Diagnosing, managing, and preventing salivary gland disorders. Oral Diseases 8:2, 77-89. [CrossRef]

32. Doron J. Aframian, Changyu Zheng, Corinne M. Goldsmith, Janeta Nikolovski, Edna Cukierman , Kenneth M. Yamada , David J. Mooney, Henning Birkedal-Hansen, Bruce J. Baum . 2001. Using HSV-Thymidine Kinase for Safety in an Allogeneic Salivary Graft Cell LineUsing HSV-Thymidine Kinase for Safety in an Allogeneic Salivary Graft Cell Line. Tissue Engineering 7:4, 405-413. [Abstract] [PDF] [PDF Plus]

33. SHINO YASHIKI, RYOTA UMEGAKI, MASAHIRO KINO-OKA, MASAHITO TAYA. 2001. Evaluation of Attachment and Growth of Anchorage-Dependent Cells on Culture Surfaces with Type I Collagen Coating. Journal of Bioscience and Bioengineering 92:4, 385-388. [CrossRef] 